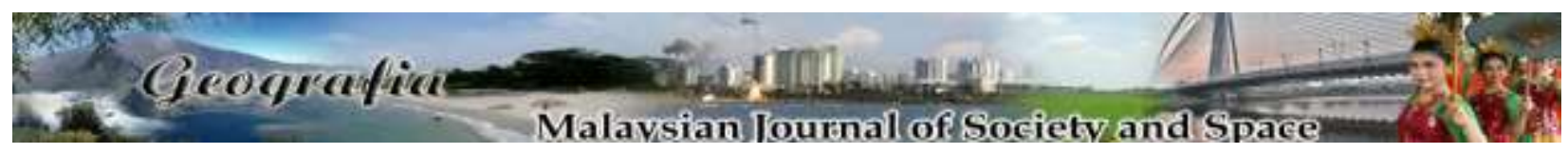

\title{
Analysis of land use and land cover change of Sidon City, Lebanon
}

\author{
Lam Kuok Choy, Mokhtar Jaafar, Layal Abdul Rahim Halime, Nur Hakimah Asnawi, \\ Rosniza Aznie Che Rose \\ Geography Programme, \\ Center for Research in Development, Social \& Environment (SEEDS), \\ Faculty of Social Sciences and Humanities, Universiti Kebangsaan Malaysia. \\ Correspondence: Mokhtar Jaafar (m_jaafar@ukm.edu.my)
}

Received: 24 September 2019; Accepted: 23 March 2020; Published: 28 August 2020

\begin{abstract}
The rapid industrialization and urbanization of an area requires quick preparation of actual land use and land cover (LULC) maps in order to detect and avoid overuse and damage of the landscape beyond sustainable development limits. Remote sensing technology fits well for longterm monitoring and assessment of such effects. The aim of this study is to analyze the expansion of urbanization and LULC changes in Sidon City, Lebanon between 1985 and 2015. The study site is a fast growing region. Therefore, monitoring land changes is an important issue in landscape planning and resource management. In this study, an analysis is carried out for LULC changes in Sidon district via satellite imagery and geographic information systems (GIS). The applied methods consist of two major components: remote sensing-based land classification and GIS-based land change analysis. Seven land cover classes have been detected for evaluating and quantifying the land cover changes for each class within the time frame series from 1985 and 2015. The final results in this study shows the urban expansion and built up areas were clearly detected. Built-up areas took over various unused open areas and in many cases it replaced different agricultural lands. Also results shows the agricultural land changes where some crop types dominates others in some areas and some has been completely transformed to built-up areas. The result from this research indicates that the civil war and conflict with neigbhouring countries brings decline in agricultural areas, impacting the economic aspect of agro trading and destruction of property and development. Yet, after the conflicts ended, Saidon saw significant increase in urbanisation and development activities at local scale.
\end{abstract}

Keywords: GIS, land-use, land-cover, remote sensing, Sidon, urban expansion

\section{Introduction}

In many developing countries, rapid urban expansion is characterized by fast population growth and unsystematic developmental activities which often leads to the changes in land use and land cover. The fast changing of land use and land cover due to urbanization, in addition to the 
industrial revolution, can be easily noticed through the development of suburban areas and changes to the city centre driven by the improving economy and technology. If left unchecked, the rapid changes in land use and land cover may cause overuse beyond the limits of the sustainable development. Consequently, ground information of land use and land cover changes are important for land management, monitoring and urban planning (Coskun, Alganci \& Usta, 2008).

Lebanon's Sidon district, as well as other coastal areas, has become one of the most threatened areas because of the industrial and commercial activities in addition to the high population pressure due to urban sprawl. According to the Darwich (2011), Sidon suffers from intrinsic factors that leads to weak management of the district. Some of these factors includes: limited presence of the government ministries in peripheral regions, haphazard housing and unchecked urban expansion, lack of enforcement of building codes, lack of regulation of land use, and frequent military conflicts or wars. Herein, assessing the land use and land cover changes is a necessary matter for understanding the land use and land cover changes scenarios and for assessing the land use management and planning. Hence, land use and land cover change detection is crucial in detecting such effects, driving forces, and predicting the consequences that may take place due to the land changes (Jeanne et al., 1995).

Change detection is the process of identifying differences in the state of an object or phenomenon by remotely observing it at different times (Singh, 1989). It has been increasingly important to understand the past implications of the human land-use, as well as the present and the future patterns (Lee et al. 1992). In order to understand how do the earth systems are being affected and how do they interact with the land-use changes, we need data of what changes occurred, where and when, the rates, and an accurate ground information about the forces derived to these changes (Lambin 1997; Read et al. 2001).

Change detection has become a major application and essential for monitoring land use and land cover changes. Remote sensing and geographic information system (GIS) have been recognize as low cost efficient tools, which have been widely used, to detect and develope land use and land cover change information over large areas (Lunetta, 2006). Over the last few decades, remote sensing techniques has been discussed and applied by numerous scholars in land use and land cover change detection studies (Mukherjee, 1987; Quarmby \& Cushine, 1989; Lambin \& Strahler, 1993; Roberts et al., 1998; Mas, 1999; Hayes \& Sader, 2001; Rogan et al., 2002; Walker, 2003; Deszo 2004; Woodcock \& Ozdogan, 2004; Rhemtulla, Mladenoff \& Clayton, 2007; Fan 2007; Wilkinson, Parker \& Evans, 2008; Narimah, 2010; Panahi 2010; Praveen \& Jayarama, 2013; Sumayyah \& Zullyadini, 2016; Nur Hakimah \& Lam, 2016; Lam \& Hay, 2017; Zurinah Tahir \& Jalaludin Abdul Malek, 2017; Nur Syabeera \& Firuza, 2019). remote sensing applications and GIS are capable of generating fast and accurate information of the spatial distribution of land use and land cover over large area (Zsuzsanna, Bartholy, Pongracz \& Barcza, 2005; Rogana \& Chen, 2004; Guerschman et al., 2003; Carlson \& Azofeifa, 1999).

Thus, by using RS and GIS techniques, plans can be easily developed for various uses of the natural resources and the preservation of nature, and to overcome the problems of chaotic urban sprawl as well as the problem of losing prime agricultural lands and forests (James 2001). Lu et al. (2004) discusses the various techniques of detecting changes that have been developed, such as component principal analysis techniques, post-classification comparison, image differentiation, image ratio, image regression, manual on screen digitization and image classification of various dates. The study by Yuan et al. (2005) and Mas (1999) have compared various techniques to detect change and the post-classification techniques is found to be the most 
appropriate procedure and have the advantage of showing the nature of change. Postclassification comparisons of derived thematic maps go beyond simple change detection and attempt to quantify the different types of change. The degree of success depends upon the reliability of the maps made by image classification. Based on literature discussion, remote sensing and GIS approaches are best suited to analyzing land use and land cover changes occurring in an area. Therefore, the main aim of this paper is to investigate the LULC changes and to analyze the urban expansion in Sidon district through the application of remote sensing and GIS techniques for monitoring the changes between 1985 and 2015.

\section{Study area}

Sidon district is one of three districts of the South Lebanon Governorate. Its administrative centre is locate in Saida (Sidon). Sidon district is located in the southern part of the Lebanon between $33^{\circ} 19^{\prime} 15^{\prime \prime} \mathrm{N}$ to $33^{\circ} 35^{\prime} 20^{\prime \prime} \mathrm{N}$ and $35^{\circ} 14^{\prime} 42^{\prime \prime} \mathrm{E}$ to $35^{\circ} 30^{\prime} 10^{\prime \prime} \mathrm{E}$ as shown in Figure 1. Sidon district is one of the district within the South Governorate of Lebanon. Sidon is located on the eastern coast of the Mediterranean Sea parallel to main highways in the country and is the capital of the southern region of Lebanon. Most of the commercial and industrial infrastructures are built in Sidon. Consequently, the district faces high population density and large built-up areas.

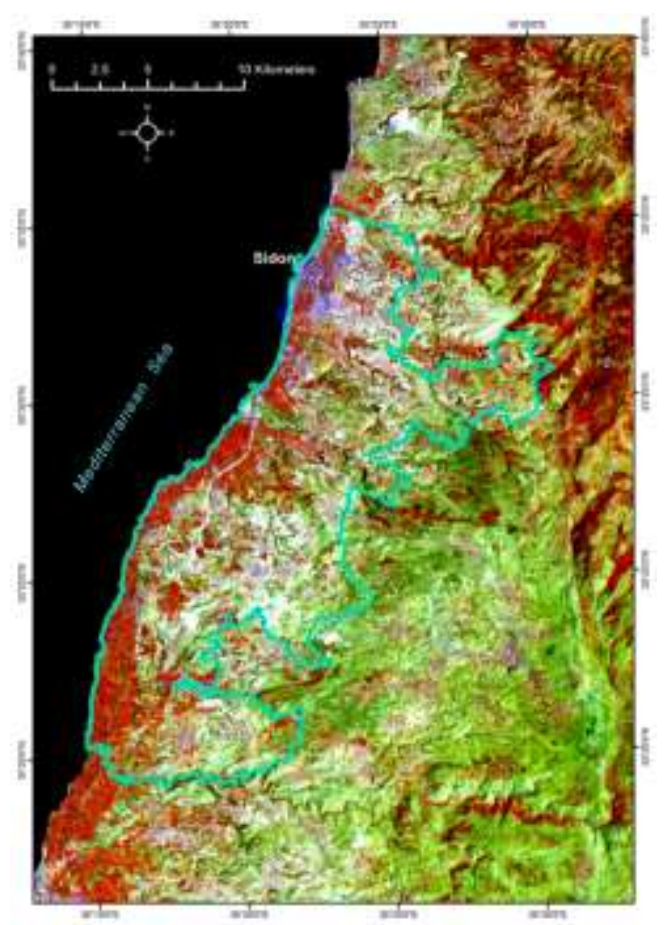

Figure 1. Map of Sidon district, Lebanon

On the other hand, the climate and the city's nature with hills was suitable for many plantations especially olives, citrus, bananas and vegetables. The climate in Sidon is warm and temperate. It is characterized by four distinct seasons: hot summer (June, July and August), warm autumn (September, October, November), cold winter (December, January and February), warm spring (March, April and May). Humidity can reach 90 percent. The average annual 
precipitation is around $732 \mathrm{~mm}$ and falls mostly during the winter, whereas there is relatively little rain during the summer. This location is classified as Csa by Köppen and Geiger (Climatedata.org, 2019). During summer mmonth of July and August, the temperature can raises to over $30{ }^{\circ} \mathrm{C}$ and sometimes $40{ }^{\circ} \mathrm{C}$ (Verner et al., 2018). The average annual temperature in Sidon hover around $20.4{ }^{\circ} \mathrm{C}$ (Climatedata.org, 2019).

\section{Materials and methods:}

The following describes the data used and methods adopted in this study that covers the satellite imagery pre-processing steps, land use classification, accuracy assessment method, and land use and land cover change detection. Figure 2 shows the overall workflow of the land use change analysis implemented in a GIS. First, the Landsat dataset was collected from the USGS website for the years of 1985 and 2015. The 1985 imagery was acquired by Landsat 4 mission on $21^{\text {st }}$ June whereas the 2015 imagery was acquired by Landsat 8 mission on $8^{\text {th }}$ June. Figure 3 shows a typical Landsat full scene covering the study area (image acquired in 2015).

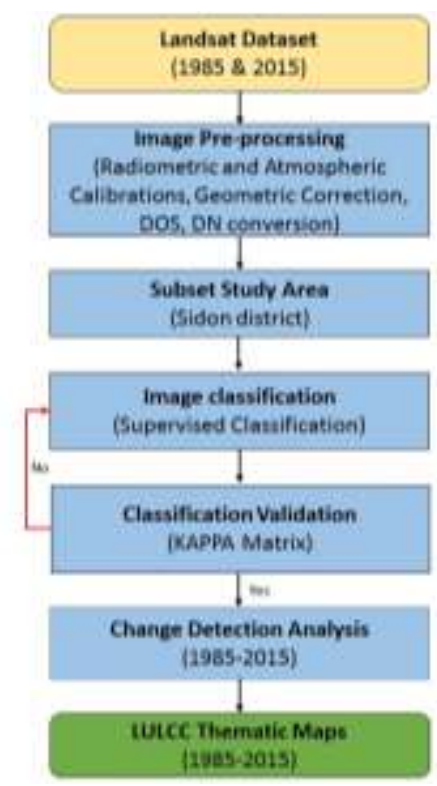

Figure 2. Overall workflow of LULC mapping for change detection analysis in Sidon City, Lebanon.

The satellite data were subjected to pre-processing steps to reduce any inherent errors. In this stage, each image was radiometrically calibrated by converting the Digital Number into radiance value using gain and offset parameters provided in metadata of the image. Thereafter, the radiance values were converted into reflectance values and atmospherically corrected using the Dark-Object Subtraction (DOS) method. Next, the images were geometrically corrected using the 2015 as a reference map. Overall, 25 spatially balanced ground control points were selected in road intersections, corners, and other clearly distinguishable points. Once the images were corrected, the study area was subset according to the boundary of Sidon area.

Each of the geometrically corrected image was classified using a supervised classification approach. The classification was carried out using Support Vector Machine (SVM) approach where training sample for land use or land cover unit were sampled from the imagery. The LULC identified from the SVM classification are urban, olives, citrus, banana, low vegetation, 
dense vegetation and open areas. To test the accuracy of the classified land use class, each classification map was validated using the KAPPA matrix and prepared for change detection analysis. The image differencing method was used to create thematic change maps for the period 1985-2015.

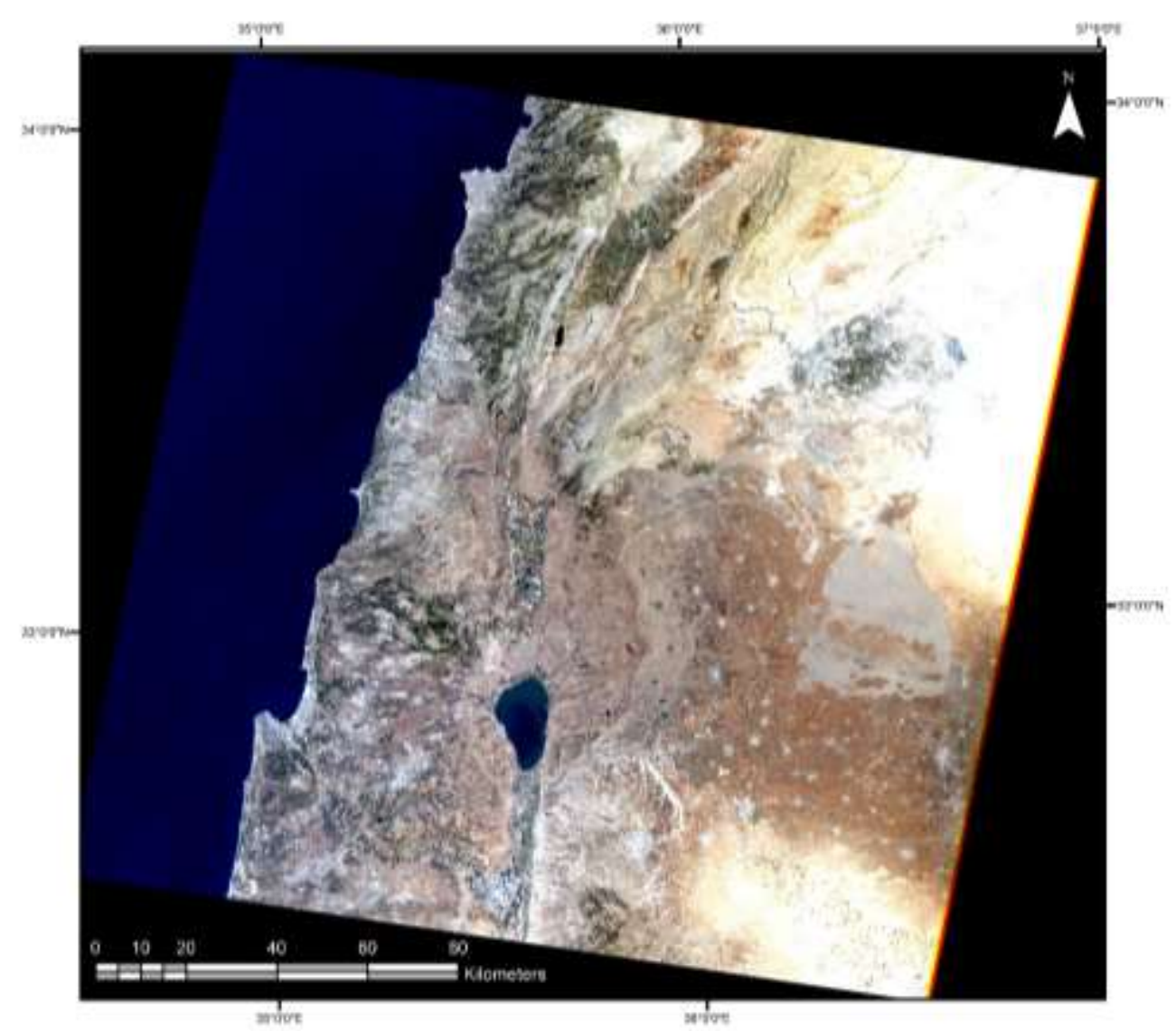

Figure 3. A full scene Landsat satellite image of the study area acquired in 2015

\section{Result and discussion}

\section{Accuracy assessment of classified land use and land cover maps}

Map accuracy refers to the assessment of the proportion of agreement between a classified thematic map and the reference or ground truth data that is assumed to be true or correct. Accuracy assessment is calculated using the Kappa analysis for the classified images to assess the accuracy of the classified LULC maps. The classified LULC map from the 1985 Landsat imagery is compared to the 1988 LULC vector map provided by CNRS whereas the 2015 classified LULC map is compared to high-resolution imagery via Google Earth. The result of the accuracy assessment is shown in Table 1. The accuracy assessment for the thematic maps shows an overall accuracy of $81 \%$ for the LULC map 1985 and KAPPA agreement of 0.74 . Whereas accuracy assessment results show an overall accuracy of $71 \%$ for the LULC map 2015 and KAPPA agreement of 0.63 . 
Table 1. Accuracy assessment results for LULC maps 1985 and 2015

\begin{tabular}{|c|c|c|c|c|}
\hline \multirow{4}{*}{ Class } & \multicolumn{4}{|c|}{ Classification Accuracy } \\
\hline & 1985 & & 2015 & \\
\hline & User & Producer & User & Producer \\
\hline & Accuracy & Accuracy & Accuracy & Accuracy \\
\hline Banana & 85 & 85 & 100 & 42 \\
\hline Citrus & 86 & 92 & 75 & 98 \\
\hline Dense Vegetation & 100 & 85 & 26 & 23 \\
\hline Olives & 67 & 70 & 30 & 25 \\
\hline Open Area & 88 & 84 & 57 & 54 \\
\hline Low Vegetation & 75 & 86 & 85 & 94 \\
\hline Urban & 80 & 88 & 89 & 98 \\
\hline Overall Accuracy & $81 \%$ & & $79 \%$ & \\
\hline Kappa & 0.74 & & 0.63 & \\
\hline
\end{tabular}

Source: GIS analysis

\section{Land use and land cover classification map}

The distribution of LULC per class area for the respective study period was shown in Table 2. In 1985 the largest LULC composed of low vegetation area which covers $102.18 \mathrm{~km}^{2}$. This is followed respectively by olives $\left(62.33 \mathrm{~km}^{2}\right)$, citrus $\left(45.82 \mathrm{~km}^{2}\right)$, urban areas $\left(30.39 \mathrm{~km}^{2}\right)$, open areas $\left(16.4 \mathrm{~km}^{2}\right)$, dense vegetation $\left(13.16 \mathrm{~km}^{2}\right)$ and banana $\left(2.09 \mathrm{~km}^{2}\right)$. Meanwhile in 2015 , low vegetation areas remained the largest LULC area but a noticeable decrease was reported where it has declined to $75.71 \mathrm{~km}^{2}$. This is followed by the urban, olives and citrus areas which increased to $60.19 \mathrm{~km}^{2}, 64.4 \mathrm{~km}^{2}$ and $53.3 \mathrm{~km}^{2}$ respectively. Whereas open areas, dense vegetation and banana areas decreased to $9.76 \mathrm{~km}^{2}, 5.55 \mathrm{~km}^{2}$ and $4.56 \mathrm{~km}^{2}$ respectively. The spatial distribution of the LULC for respectively year was shown in Figure 4 and 5.

Table 2. Land use and land cover per class area for 1985 and 2015

\begin{tabular}{lllll}
\hline \multirow{2}{*}{ Class } & \multicolumn{4}{c}{ Area $\left(\mathbf{k m}^{\mathbf{2}}\right)$} \\
\cline { 2 - 5 } & $\mathbf{1 9 8 5}$ & $\mathbf{\%}$ & $\mathbf{2 0 1 5}$ & $\mathbf{\%}$ \\
\hline Urban & 30.39 & 11.16 & 60.19 & 22.01 \\
Olives & 62.33 & 22.88 & 64.4 & 23.55 \\
Citrus & 45.82 & 16.82 & 53.3 & 19.49 \\
Banana & 2.09 & 0.77 & 4.56 & 1.67 \\
Low Vegetation & 102.18 & 37.52 & 75.71 & 27.68 \\
Dense Vegetation & 13.16 & 4.83 & 5.55 & 2.03 \\
Open Area & 16.4 & 6.02 & 9.76 & 3.57 \\
Total & $\mathbf{2 7 2 . 3 7}$ & $\mathbf{1 0 0 . 0 0}$ & $\mathbf{2 7 3 . 4 7}$ & $\mathbf{1 0 0 . 0 0}$ \\
\hline
\end{tabular}

Source: GIS analysis 


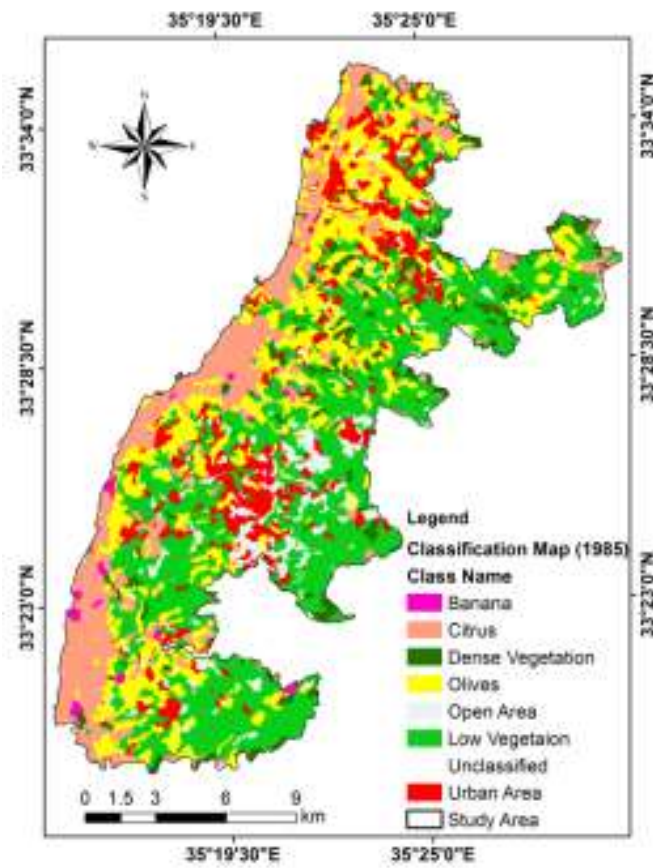

Figure 4. LULC classification map (1985)

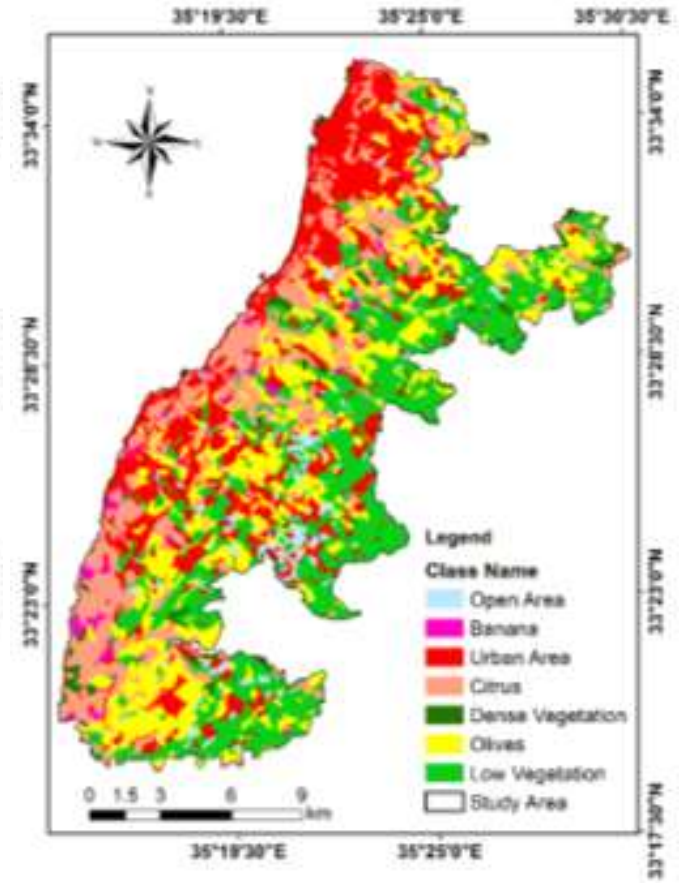

Figure 5. LULC classification map (2015)

\section{Lulc change detection result}

The spatial distribution of the LULC change between 1985 and 2015 is shown in figure 6. The LULC change result calculated as per class changes in square $\mathrm{km}$ for the study period is summarized and presented in figure 7 and table 3 shows the change matrix for each classes.

The main LULC classes in this study were divided into seven classes: urban areas, olives, citrus, bananas, low vegetation, dense vegetation, and open areas. Between 1985 and 2015, urban areas in Sidon district increased by 98.06 percent from $30.39 \mathrm{~km}^{2}$ in 1985 to $60.19 \mathrm{~km}^{2}$ by 2015 . Urban expansion recorded the highest per class increment among the land use classes, where the largest change area was recorded from olives to urban land use (6.24\%). In term of classified agriculture crops, olives, citrus, and bananas cover the study area. Olives covered the largest areas of planted land at $62.33 \mathrm{~km}^{2}$ in 1985 and increased to $64.4 \mathrm{~km}^{2}$ by 2015 . This is followed by citrus plantations occupying $45.82 \mathrm{~km}^{2}$ in 1985 and increased by 16.32 percent to $53.3 \mathrm{~km}^{2}$ in 2015 due to the plantation plans or scheme, which is supported by the government. On the other hand, the bananas crop occupy the smallest planted areas at approximately $2.09 \mathrm{~km}^{2}$ in 1985 and it increased to $4.56 \mathrm{~km}^{2}$ by 2015 .

Asides from agricultural crops, other green area is classified into either dense vegetation and low vegetation covered areas. Low vegetation areas make up the largest land cover in term of per class coverage within the study area. Low vegetation areas mainly consists of grass-shrub dotted areas, which covers approximately $102.18 \mathrm{~km}^{2}$ in 1985 down to $75.71 \mathrm{~km}^{2}$ by 2015 , showing a 34.96 percent decline. Whereas the dense vegetation area saw the largest per class decline at 137.12 percent from $13.16 \mathrm{~km}^{2}$ in 1985 to $5.55 \mathrm{~km}^{2}$ by 2015 . The same declining trend also affect open areas, which decreased from $16.4 \mathrm{~km}^{2}$ in 1985 to $9.76 \mathrm{~km}^{2}$ by 2015. That was due to the increase in population and the reconstruction plans after the war with Israel during 
which many buildings and main roads have been destroyed by the bombs dropped by Israel planes (Masri, Khawlie \& Faour, 2002).

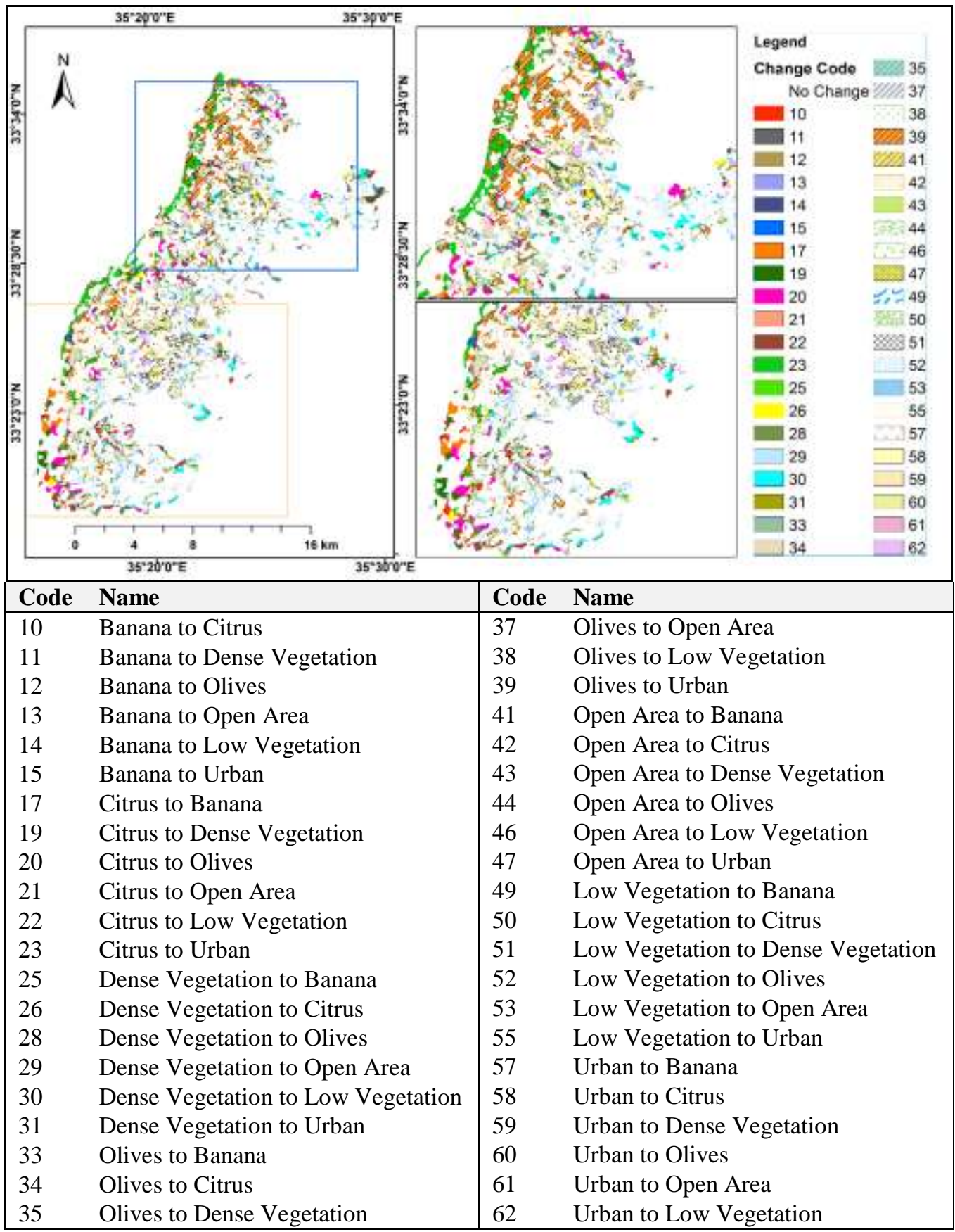

Figure 6. LULC change map between 1985 and 2015 
GEOGRAFIA Online ${ }^{\mathrm{TM}}$ Malaysian Journal of Society and Space 16 issue 3 (108-120)

(C) 2020, e-ISSN 2682-7727 https://doi.org/10.17576/geo-2020-1603-09

Table 3. Calculated changes in class area from 1985 and 2015

\begin{tabular}{|c|c|c|c|}
\hline Class_1985 & Class_2015 & Area $\left(\mathbf{k m}^{2}\right)$ & Percent \\
\hline \multicolumn{2}{|c|}{ No Change } & 106.0164 & $38.52 \%$ \\
\hline Banana & Citrus & 1.0125 & $0.37 \%$ \\
\hline Banana & Dense Vegetation & 0.0585 & $0.02 \%$ \\
\hline Banana & Olives & 0.0612 & $0.02 \%$ \\
\hline Banana & Open Area & 0 & $0.00 \%$ \\
\hline Banana & Low Vegetation & 0.1458 & $0.05 \%$ \\
\hline Banana & Urban & 0.3942 & $0.14 \%$ \\
\hline Citrus & Banana & 2.1258 & $0.77 \%$ \\
\hline Citrus & Dense Vegetation & 2.0115 & $0.73 \%$ \\
\hline Citrus & Olives & 6.2163 & $2.26 \%$ \\
\hline Citrus & Open Area & 0.2583 & $0.09 \%$ \\
\hline Citrus & Low Vegetation & 2.5992 & $0.94 \%$ \\
\hline Citrus & Urban & 9.3294 & $3.39 \%$ \\
\hline Dense Vegetation & Banana & 0.0513 & $0.02 \%$ \\
\hline Dense Vegetation & Citrus & 2.1078 & $0.77 \%$ \\
\hline Dense Vegetation & Olives & 2.7963 & $1.02 \%$ \\
\hline Dense Vegetation & Open Area & 0.2034 & $0.07 \%$ \\
\hline Dense Vegetation & Low Vegetation & 5.2236 & $1.90 \%$ \\
\hline Dense Vegetation & Urban & 1.1646 & $0.42 \%$ \\
\hline Olives & Banana & 0.7866 & $0.29 \%$ \\
\hline Olives & Citrus & 13.1058 & $4.76 \%$ \\
\hline Olives & Dense Vegetation & 0.5733 & $0.21 \%$ \\
\hline Olives & Open Area & 0.892800 & $0.32 \%$ \\
\hline Olives & Low Vegetation & 10.4049 & $3.78 \%$ \\
\hline Olives & Urban & 17.1864 & $6.24 \%$ \\
\hline Open Area & Banana & 0.0441 & $0.02 \%$ \\
\hline Open Area & Citrus & 0.9477 & $0.34 \%$ \\
\hline Open Area & Dense Vegetation & 0.1008 & $0.04 \%$ \\
\hline Open Area & Olives & 3.2814 & $1.19 \%$ \\
\hline Open Area & Low Vegetation & 3.7242 & $1.35 \%$ \\
\hline Open Area & Urban & 4.6890 & $1.70 \%$ \\
\hline Low Vegetation & Banana & 0.4851 & $0.18 \%$ \\
\hline Low Vegetation & Citrus & 6.7230 & $2.44 \%$ \\
\hline Low Vegetation & Dense Vegetation & 1.6695 & $0.61 \%$ \\
\hline Low Vegetation & Olives & 22.5351 & $8.19 \%$ \\
\hline Low Vegetation & Open Area & 4.6026 & $1.67 \%$ \\
\hline Low Vegetation & Urban & 20.6244 & $7.49 \%$ \\
\hline Urban & Banana & 0.1962 & $0.07 \%$ \\
\hline Urban & Citrus & 3.6405 & $1.32 \%$ \\
\hline Urban & Dense Vegetation & 0.3213 & $0.12 \%$ \\
\hline Urban & Olives & 9.9603 & $3.62 \%$ \\
\hline Urban & Open Area & 1.1169 & $0.41 \%$ \\
\hline Urban & Low Vegetation & 5.8635 & $2.13 \%$ \\
\hline Total & & 275.2515 & $100.00 \%$ \\
\hline
\end{tabular}




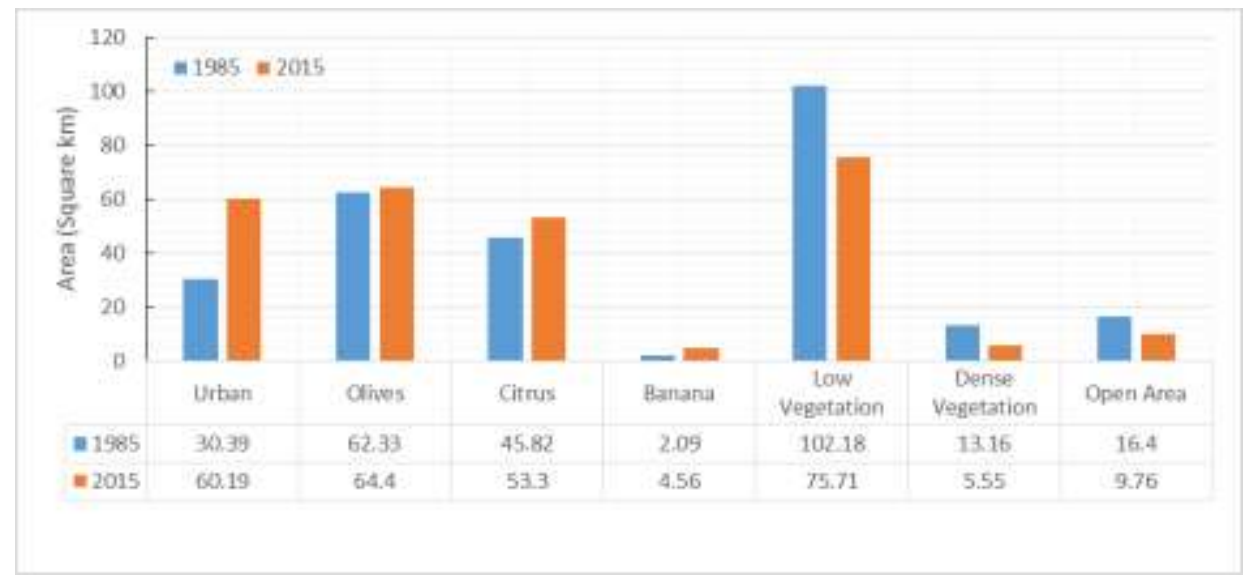

Source: GIS analysis

Figure 7. Changed areas per class for the study period

\section{Discussion}

Based on the LULC change detection result, it was clearly noticed the various changes of the per class LULC throughout the study period. Various different factors cause this change. One of the main factor is due to military conflict. According to Masri, Khawlie and Faour (2002), the 1975 to 1990 crisis and the Israeli military aggressions resulted in large swath of agricultural and natural cover being damaged and causing land degradation over large area. The war with Israel during the 1990s saw large areas of urban settlement and agricultural area, especially olive plantation in the city of Qana, being destroyed (Masri, Khawlie \& Faour, 2002). According to the statement from the Council for Development and Reconstruction, Ministry of Agriculture, the olives plantations were burnt down by the bomb dropped by the Israeli planes. The situation caused hardship to the farmers and after the war ended, most of the areas were replanted with fast harvest crops such as bananas due to growing demand for export and expanding trade line with other countries.

Urban expansion is clearly detected in LULC change detection result. Built-up areas took over various unused open areas and in many cases it replaced different agricultural lands. Between the period of 1985 and 2015, urban areas expansion lead to 98 percent increase from $30.39 \mathrm{~km}^{2}$ to $60.19 \mathrm{~km}^{2}$ by the end of the study period. This scenario is similar to the earlier conflict era whereby from 1960s to 1990s, Lebanon recorded urbanization increased locally anywhere from 25\% to more than 100\% (Masri, Khawlie \& Faour, 2002). Refering to figure 6, most of the urban expansion took place over olive and low vegetation areas. Built-up areas increased not only because of the normal population growth but also due to the huge numbers of refugees came from Syria since 2010 because of the civil war and the unstable security conditions in their country.

The changing of trade line for the exported commodities of the country was another important factor contributing to the changes in LULC. Consequently, many planted areas were replaced by another type of plantation according to the need of the trading countries. Changing of trade line of Lebanon was unavoidable after the civil war in Syria (the nearest country to Lebanon) began in 2010. Before 2010, most of the vegetation, banana and citrus crops were exported to Syria and to another countries from that trade line with Syria. After the Syrian war 
began in 2010, Lebanese crops economy faced a great loss since exporting crops became difficult and even impossible. Trade line changed to the Emirates which were importing from Syria before the war. The most needed crops for the new trade line were citrus fruits and the new demand saw the increase of planted areas of citrus crops (World Bank, 2013; Calì et al., 2015).

\section{Conclusion}

This study shows an integrated GIS and remote sensing approach to detect and analyze changes in LULC over Sidon district. The Landsat satellite data for the study period of 1985 and 2015 were used to generate land cover maps through a maximum likelihood supervised image classification algorithm. The remote sensing image classification result was able to shows the various per class changes of LULC. There was a rapid changing in built up areas and agricultural areas as well which saw the size of both LULC classes increased significantly. In Lebanon there has been lacking in the land use and land cover change study or research. The previous study was dated which cover the period between 1963 and 1998. In this study, the research covers the period from 1985 up to 2015 and represent the more recent development in LULC changes in modern Lebanon. The result from both research indicates that the conflict period brings decline in agricultural areas, impacting the economic aspect of agro trading and destruction of property and development. Yet, after the conflicts ended, both period saw significant increase in urbanisation and development activities at national or local scale. Land use change result provided an important spatio-temporal information of land use and land cover changes. It also provide the possibility to understand the influence and dynamics of LULC change supported by a set of drivers. The result of this research can provide important information for Sidon's decision makers for better land use monitoring.

\section{References}

Calì, M., Harake, W., Hassan, F., \& Struck, C. 2015. The impact of the Syrian conflict on Lebanese trade. Washington, World Bank Report, \#96087. Accessed from http://documents.worldbank.org/curated/en/908431468174247241/pdf/96087-WPP148051-PUBLIC-Box391435B-Syria-Trade-Report.pdf

Carlson, T. N., \& Azofeifa, S. G. A. (1999). Satellite remote sensing of land use changes in and around San Jose', Costa Rica. Remote Sensing of Environment, 70(3), 247-256.

Climatedata.org. 2019. Sidon climate. Accessed from https://en.climate-data.org/asia/lebanon/ sidon/sidon-4859/

Coskun, H.G., Alganci, U., \& Usta, G. (2008). Analysis of land use change and urbanization in the Kucukcekmece Water Basin (Istanbul, Turkey) with temporal satellite data using remote sensing and GIS. Sensors, 8(11): 7213-7223.

Darwish, T. (2011, March). Land use planning: Prerequisite for sustainable management of land resources in Lebanon. Al Mouhandess, 26:14-19.

Dezso Z., Bartholy J., Pongracz R., \& Barcza Z. (2005). Analysis of land-use/land-cover change in the Carpathian region based on remote sensing techniques. International Journal of Geomatics and Geosciences, 4(2): 109-115.

Fan, F., Weng, Q., \& Wang, Y. (2007). Land use land cover change in Guangzhou, China, from 1998 to 2003, based on Landsat TM/ETM+ imagery. Sensors, 7, 1323-1342. 
Guerschman, J. P., Paruelo, J. M., Bela, C. D., Giallorenzi, M. C., \& Pacin, F. (2003). Land cover classifcation in the Argentine Pampas using multi-temporal Landsat TM data. International Journal of Remote Sensing, 24(17), 3381-3402.

Hayes, D.J., \& Sader, S.A. (2001). Comparison of change detection techniques for monitoring tropical forest clearing and vegetation regrowth in a time series. Photogrammetric Engineering and Remote Sensing, 67, 1067-1075.

Jeanne, X.K., Roger, E.K. \& Turner II, B.L. (1995). Region at Risk: Comparisons of Threatened Environments. p. 536-570. United Nations University Press, Tokyo.

Praveen, K. M., \& Jayarama R. S. R. (2013). Analysis of land use/land cover changes using remote sensing data and GIS at an urban area, Tirupati, India. The Scientific World Journal, 1, 1-6. doi:10.1155/2013/268623

Lam Kuok Choy, \& Hay Ah Na. (2017). Mengesan perubahan guna tanah dan litupan bumi menggunakan kaedah penderiaan jauh di Daerah Miri, Sarawak. Geografi, 5(3), 85-94.

Lambin, E. F., \& Strahler, A. H. (1993). Change-vector analysis in multitemporal space: A tool to detect and categorize land-cover change processes using high-temporal resolution satellite data. Remote Sensing of Environment, 48, 231-244.

Lu, D., Mausel, P., Brondízio, E., \& Moran, E., (2004). Change detection techniques; International Journal of Remote Sensing, 25:12, 2365-2407.

Lunetta, R.L., Knight, F.K., Ediriwickrema, J., Lyon, J.G., \& Worthy, L.D. (2006). Land cover change detection using multi-temporal MODIS NDVI data. Remote Sensing of Environment, 105(2): 142-154.

Mas, J.F. (1999). Monitoring land-cover changes: A comparison of change detection techniques. International Journal of Remote Sensing, 20(1), 139-152.

Masri, T., Khawlie, M., \& Faour, G. 2002. Land cover change over the last 40 years in Lebanon. Lebanese Science Journal, 3(2), 1-13.

Mukherjee, S. (1987). Landuse maps for conservation of ecosystems. Geogr. Rev. Ind. 3, 23-28.

Narimah Samat. (2010). Assessing land use land cover changes in Langkawi Island: Towards sustainable urban living. Malaysian Journal of Environmental Management. 11(1), 4857.

Nur Hakimah, A., \& Lam Kuok Choy. (2016). Analisis perubahan guna tanah dan litupan bumi di Gombak, Selangor menggunakan data penderiaan jauh. Sains Malaysiana, 45(12), 1869-1877

Nur Syabeera Begum Nasir Ahmad, \& Firuza Begham Mustafa. (2019). Analisis perubahan guna tanah Negeri Sembilan melalui aplikasi Sistem Maklumat Geografi (GIS). GeografiaMalaysian Journal of Society and Space, 15(1), 113-131. https://doi.org/10.17576/geo2019-1501-09

Panahi, A., Alijani, B., \& Mohammadi, H. (2010). The effect of the land use/cover changes on the floods of the Madarsu Basin of North eastern Iran. J. Water Resource and Protection, 2(4): 373-379.

Quarmby, N.A., \& Cushine, J.L. (1989). Monitoring urban land cover changes at the urban fringe from SPOT HRV imagery in South East England. Int. J. Rem. Sens. 10(6), 231251.

Rhemtulla, J. M., Mladenoff, D. J., \& Clayton, M. K. (2007). Regional land-cover conversion in the U.S. upper Midwest: Magnitude of change and limited recovery (1850-1935-1993) Landscape Ecology, 22, 57-75. Supplement 1/December, 2007.

Roberts, D. A., Batista, G. T., Pereira, J. L. G., Waller, E. K., \& Nelson, B. W. (1998). Change 
identification using multitemporal spectral mixture analysis: applications in eastern Amazonia. In Lunetta, R.S., \& Elvidge C.D. (Eds.), Remote Sensing Change Detection: Environmental Monitoring Methods and Applications. Chelsea, MI: Ann Arbor Press, pp. 137-161.

Rogan, J., Franklin, J., \& Roberts, D. A. (2002). A comparison of methods for monitoring multitemporal vegetation change using Thematic Mapper imagery. Remote Sensing of Environment, 80, 143-156.

Rogana, J., \& Chen, D. (2004). Remote sensing technology for mapping and monitoring landcover and land-use change. Progress in Planning, 61, 301-325.

Singh, A. (1989). Review article digital change detection techniques using remotely sensed data. International Journal of Remote Sensing, 10(6), 989-1003.

Sumayyah Aimi, M. N., \& Zullyadini, A. R. (2016). Analisis perubahan gunatanah di Daerah Barat Daya, Pulau Pinang. Geografi, 4(1), 43-55.

Verner, D., Ashwill, M.S., Christensen, J., Mcdonnell, R., Redwood, J., Jomaa, I., Saade, M., Massad, R., Chehade, A., Bitar, A., \& Treguer, D.O. 2018. Droughts and agriculture in Lebanon: Causes, consequences, and risk management. Washington, D.C.: World Bank Group. Accessed from http://documents.worldbank.org/curated/en/8923815384151220 88/Droughts-and-Agriculture-in-Lebanon-Causes-Consequences-and-Risk-Management

Walker, R. (2003). Mapping process to pattern in the landscape change of the Amazonian frontier. Annuals of the Association of American Geographers, 93(2), 376-398.

Wilkinson, D. W., Parker, R. C., \& Evans, D. L. (2008). Change detection techniques for use in a statewide forest inventory program. Photogrammetric Engineering and Remote Sensing, 74(7), 893-901.

Woodcock, C.E., \& Ozdogan, M. (2004). Trends in land cover mapping and monitoring. In Gutman, G., Janetos, A.C., Justice, C.O., Moran, E.F., Mustard, J.F., Rindfuss, R.R., Skole, D., Turner II, B.L., \& Cochrane, M.A. (Eds.), Land Change Science: Observing, monitoring and understanding trajectories of change on the earth's surface. Springer, New York, pp. 367-377.

World Bank. 2013. Lebanon - Economic and social impact assessment of the Syrian conflict. Washington and Beirut: The World Bank.

Yuan, F., Sawaya, K. E., Loeffelholz, B. C., \& Bauer, M. E. (2005). Land cover classifcation and change analysis of the twin cities (Minnesota) metropolitan areas by multitemporal Landsat remote sensing. Remote Sensing of Environment, 98(2), 317-328.

Zurinah Tahir, \& Jalaludin Abdul Malek. (2017). Pemantauan percanggahan guna tanah bandar dan tanah pertanian menggunakan Sistem Maklumat Geografi (GIS). GeografiaMalaysian Journal of Society and Space, 13(3), 112-130.

Zsuzsanna, D., Bartholy, J., Pongracz, R., \& Barcza, Z. (2005). Analysis of land-use/land-cover change in the Carpathian region based on remote sensing techniques. Physics and Chemistry of Earth, 30, 109-115. 